\title{
Progress in retinal toxicity research
}

\author{
Hermann M. Bolt ${ }^{1}\left[\right.$. Jan G. Hengstler ${ }^{1}$
}

Received: 16 December 2021 / Accepted: 11 January 2022 / Published online: 31 January 2022

(c) The Author(s) 2022

Retinotoxicity of chemicals has been an issue for the Archives of Toxicology since decades. Already in the 1930s, we published case reports on amblyopy caused by intoxications, e.g., by arsenicals (Leinfelder 1938) and methanol (Menne 1939). At that time, arsenicals were still ingredients of a number of medicines.

Much later, significant advance of diagnostic tools, such as electroretinographic assessment of early retinopathy in rats (Maertins et al 1993), triggered a new era of research on retinotoxins, by combining morphological and physiological methods (Nyska et al 1992). Examples of toxicants examined are 2-hexanediol (Bäckström et al 1993, 1998; Nylen et al. 1993) and the antibacterial agent sitafloxacin (Shimoda et al 2001).

Currently, we witness further significant advancements in analytical tools and molecular biology. For instance, Wright et al (2019) used RNA profiling to determine the distribution of genes in the human retina, in relation to retinal toxicity. Other topics of publications were the influence of blue light (Alaimo et al 2019), and degeneration of retinal pigment epithelial cells by the toxic fluorophore $N$-retinyl- $N$-retinylidene ethanolamine (Alaimo et al 2020).

In general, ocular toxicity remains as an important aspect in preclinical testing, and refinements of the general strategy are warranted.

In this issue of the Archives of Toxicology, Hamm et al (2022) from AstraZeneca, U.K., focus on the receptor tyrosine kinase, MERTK, which plays an essential role in homeostasis of the retina, via efferocytosis of shed outer nuclear segments of photoreceptors. MERTK is a receptor tyrosine kinase and part of the TAM family that is involved in regulation of the innate immune response. There is much interest in harnessing the potential of MERTK as a novel oncolytic therapeutic target. However, a significant body of

Hermann M. Bolt

bolt@ifado.de

1 Leibniz Research Centre for Working Environment and Human Factors at TU Dortmund (IfADo), Adeystr. 67, 44139 Dortmund, Germany evidence shows that genetic mutation of MERTK is associated with retinal degeneration in rats and mice. Moreover, this phenotype translates to human loss-of-function mutations of MERTK which result in retinitis pigmentosa. Hamm et al (2022) describe a pre-clinical strategy to investigate the potential for ocular toxicity of a novel and selective MERTK inhibitor, which involved the application and integration of state of the art technologies, including multi-modal MSI, histopathology and EM. This approach enabled in-depth characterisation of an ocular lesion at both a molecular and morphological level. Furthermore, back-translation to an in vitro human retinal mode was assessed. The strategy appears equally applicable to characterise other small molecule inhibitors with a risk of ocular toxicity, which appears to be of relevance with the increasing prevalence of clinical ocular toxicity, particularly for tyrosine kinase inhibitors.

Further contributions to this topic to the Archives of Toxicology are highly welcome!

Funding Open Access funding enabled and organized by Projekt DEAL.

\section{Declarations}

Conflict of interest The authors declare no conflict of interest.

Open Access This article is licensed under a Creative Commons Attribution 4.0 International License, which permits use, sharing, adaptation, distribution and reproduction in any medium or format, as long as you give appropriate credit to the original author(s) and the source, provide a link to the Creative Commons licence, and indicate if changes were made. The images or other third party material in this article are included in the article's Creative Commons licence, unless indicated otherwise in a credit line to the material. If material is not included in the article's Creative Commons licence and your intended use is not permitted by statutory regulation or exceeds the permitted use, you will need to obtain permission directly from the copyright holder. To view a copy of this licence, visit http://creativecommons.org/licenses/by/4.0/. 


\section{References}

Alaimo A, Liñares GG, Bujjamer JM et al (2019) Toxicity of blue led light and $\mathrm{A} 2 \mathrm{E}$ is associated to mitochondrial dynamics impairment in ARPE-19 cells: implications for age-related macular degeneration. Arch Toxicol 93:1401-1415. https://doi.org/10. 1007/s00204-019-02409-6

Alaimo A, Di Santo MC, Domínguez Rubio AP et al (2020) Toxic effects of A2E in human ARPE-19 cells were prevented by resveratrol: a potential nutritional bioactive for age-related macular degeneration treatment. Arch Toxicol 94:553-572. https://doi.org/ 10.1007/s00204-019-02637-w

Bäckström B, Nylén P, Hagman M et al (1993) Effect of exposure to 2,5-hexanediol in light or darkness on the retina of albino and pigmented rats. I. Morphology. Arch Toxicol 67:277-283. https:// doi.org/10.1007/BF01974347

Bäckström B, Shibata E, Nylén P et al (1998) 2,5-Hexanedione concentrations and morphological changes within the eye of albino rat. Arch Toxicol 72:597-600. https://doi.org/10.1007/s002040050 548

Hamm G, Maglennon G, Williamson B, MacDonald R, Doherty A, Jones S, Harris J, Blades J, Harmer A, Barton P, Rawlins PB, Smith P, Winter-Holt J, McMurray L, Johansson J, Paul Fitzpatrick P, McCoull W, Coen M (2022) Pharmacological inhibition of MERTK induces in vivo retinal degeneration; a multimodal imaging ocular safety assessment. Arch Toxicol. https://doi.org/ 10.1007/s00204-021-03197-8

Leinfelder PJ (1938) Trypasamid-Amblyopie. Vergiftungsfälle (arch Toxicol) 9:A137-A140. https://doi.org/10.1007/BF02452267
Maertins T, Kroetlinger F, Sander E et al (1993) Electroretinographic assessment of early retinopathy in rats. Arch Toxicol 67:120-125. https://doi.org/10.1007/BF01973682

Menne FR (1939) Akute Methylalkohol-Vergiftung. Vergiftungsfälle (arch Toxicol) 10:A179-A180. https://doi.org/10.1007/BF024 52458

Nylén P, Bäckström B, Hagman M et al (1993) Effect of exposure to 2,5-hexanediol in light or darkness on the retina of albino and pigmented rats. II. Electrophysiology. Arch Toxicol 67:435-441. https://doi.org/10.1007/BF01977406

Nyska A, Waner T, Wormser U et al (1992) Possible pitfalls in rat extended dermal toxicity testing: an hepatic-ocular syndrome. Arch Toxicol 66:339-346. https://doi.org/10.1007/BF01973629

Shimoda K, Okawara S, Kato M (2001) Phototoxic retinal degeneration and toxicokinetics of sitafloxacin, a quinolone antibacterial agent, in mice. Arch Toxicol 75:395-399. https://doi.org/10.1007/ s002040100263

Wright P, Kelsall J, Healing G et al (2019) Differential expression of cyclin-dependent kinases in the adult human retina in relation to CDK inhibitor retinotoxicity. Arch Toxicol 93:659-671. https:// doi.org/10.1007/s00204-018-2376-8

Publisher's Note Springer Nature remains neutral with regard to jurisdictional claims in published maps and institutional affiliations. 